\title{
11 Fluxgate Gradiometer and GPR Survey to Locate and Characterize the Perimeter, Early Imperial Centre and Street Network of the Roman Town Mariana (Corsica)
}

\section{Lieven Verdonck}

\section{Introduction}

In the last decades, magnetometry and ground-penetrating radar (GPR) have become valuable methods for the non-invasive archaeological investigation of complex urban sites (see e.g. Gaffney et al. 2000; Keay et al. 2005; Benech 2007; Leckebusch and Sütterlin 2007; Neubauer et al. 2009; Linford et al. 2010; Trinks et al. 2010). This paper presents the results of fluxgate gradiometer and GPR surveys at the Roman colonia of Mariana (municipality of Lucciana, north-eastern Corsica, France; Fig. 11.1). The history of the site, the objectives of the Mariana project and the results from twentieth-century and recent excavations, historical cartography, aerial photography and geomorphological prospections are described by C. Corsi in this volume (see Chapter 10). Given the proposed model for the delimitation of the inhabited space of Mariana (Fig. 11.1, A; Corsi, this volume), the eccentricity of the 1959-1965 and 2000-2007 excavations south of the the church known as 'La Canonica' is obvious (Fig. 11.1, B). The centre of the Early Imperial town is therefore probably situated in the fields north of the church. To further clarify the location of the Imperial town centre, the town perimeter and the street network, geophysical surveys were conducted in this area, which is to a large extent devoid of aboveground structures, and is used for sheep grazing.

\section{Fluxgate gradiometer survey}

The fluxgate gradiometer survey was carried out with a Geoscan Research FM256, on parcel 81 in September 2006 (Fig. 11.1, C), and the southern part of parcel 76 in September 2007 (Fig. 11.1, D). The inline sampling interval was $0.25 \mathrm{~m}$, the transect spacing $0.50 \mathrm{~m}$. All transects were walked in eastern direction ('parallel'). Data processing included the replacement of extreme values caused by ferrous fences with dummy 


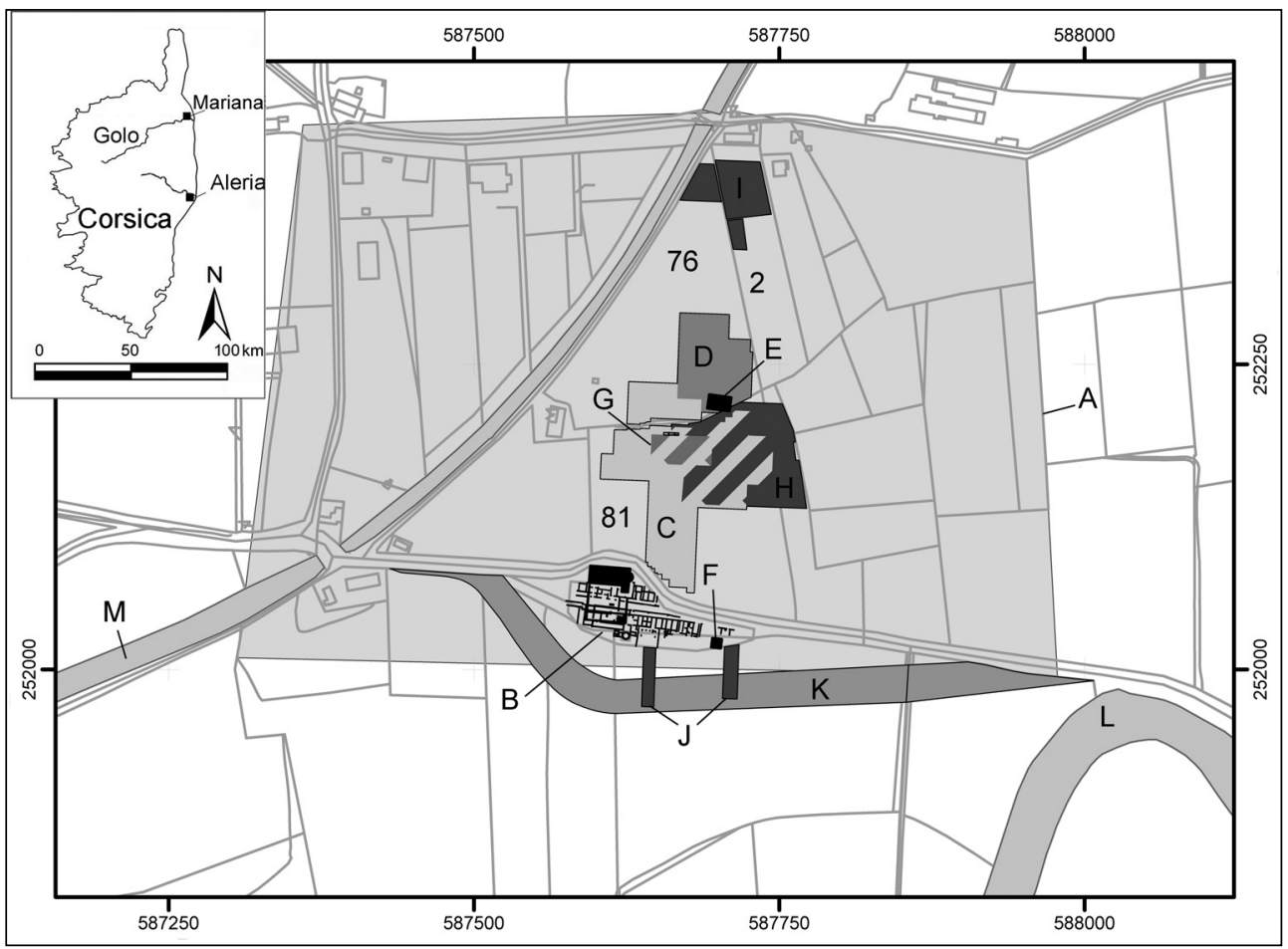

Figure 11.1: Map of Mariana. A: hypothetical extent of the town, B: excavations south of the 'La Canonica' church, C-D: fluxgate gradiometer survey area, E: 1936-1937 excavation trench ('chantier C'), F: 1936-1937 'chantier A', G: 2007 GPR survey area, H: 2008 GPR survey area, I-J: 2009 GPR survey area, K: planned section of road D107, L: Golo river, M: modern canal. The numbers refer to the parcels figuring on the cadastral map of Lucciana.

values, the application of zero-mean grid, the de-sloping of a few grids to eliminate drift and a low-pass filter to eliminate high-frequency noise and make extended, weak anomalies more clearly visible (Aspinall et al. 2008).

The results of the fluxgate gradiometer survey are presented in Figure 11.2. The walls show as linear negative anomalies (mostly around -5 to $-10 \mathrm{nT}$ from the mean). Their contrast with the parent material, mainly consisting of gravel and boulders deposited by the river Golo, is weak compared to the very numerous, strong anomalies (often exceeding $\pm 100 \mathrm{nT}$ ) caused by shallowly buried ferrous debris, masking the archaeological structures in many places. These anomalies are of limited dimensions, but often too big for a successful application of a de-spiking algorithm.

Notwithstanding this noisy background, the survey revealed a number of walls with the same orientation as the excavated structures south of 'La Canonica', approximately $\mathrm{N} 78^{\circ} \mathrm{W}$ (Figs 11.1 and 11.3). The clearest building plans can be observed in the northern 


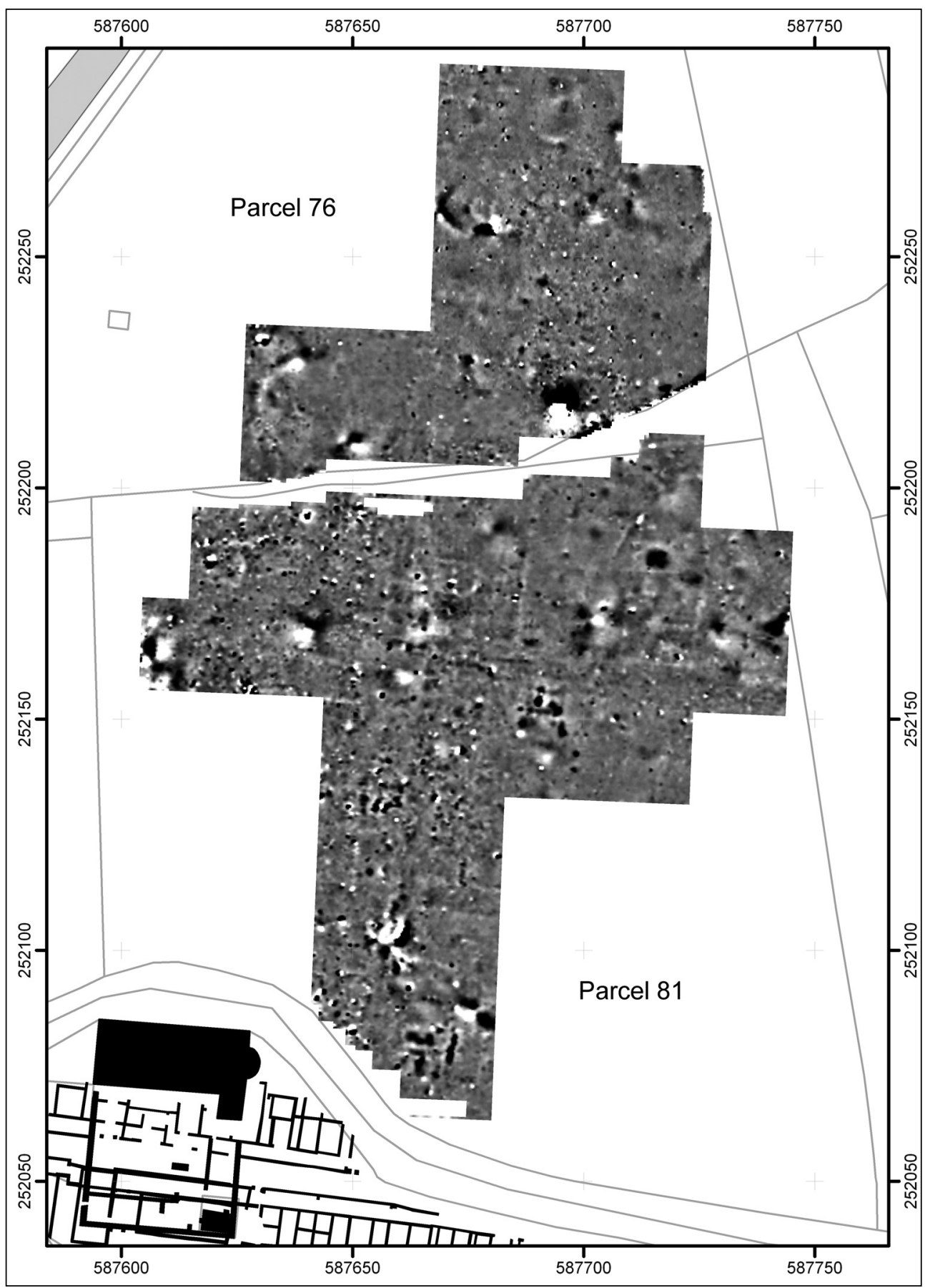

Figure 11.2: Fluxgate gradiometer survey results (2006-2007). Greyscale from $-40 \mathrm{nT}$ (white) to $+40 n T$ (black). 


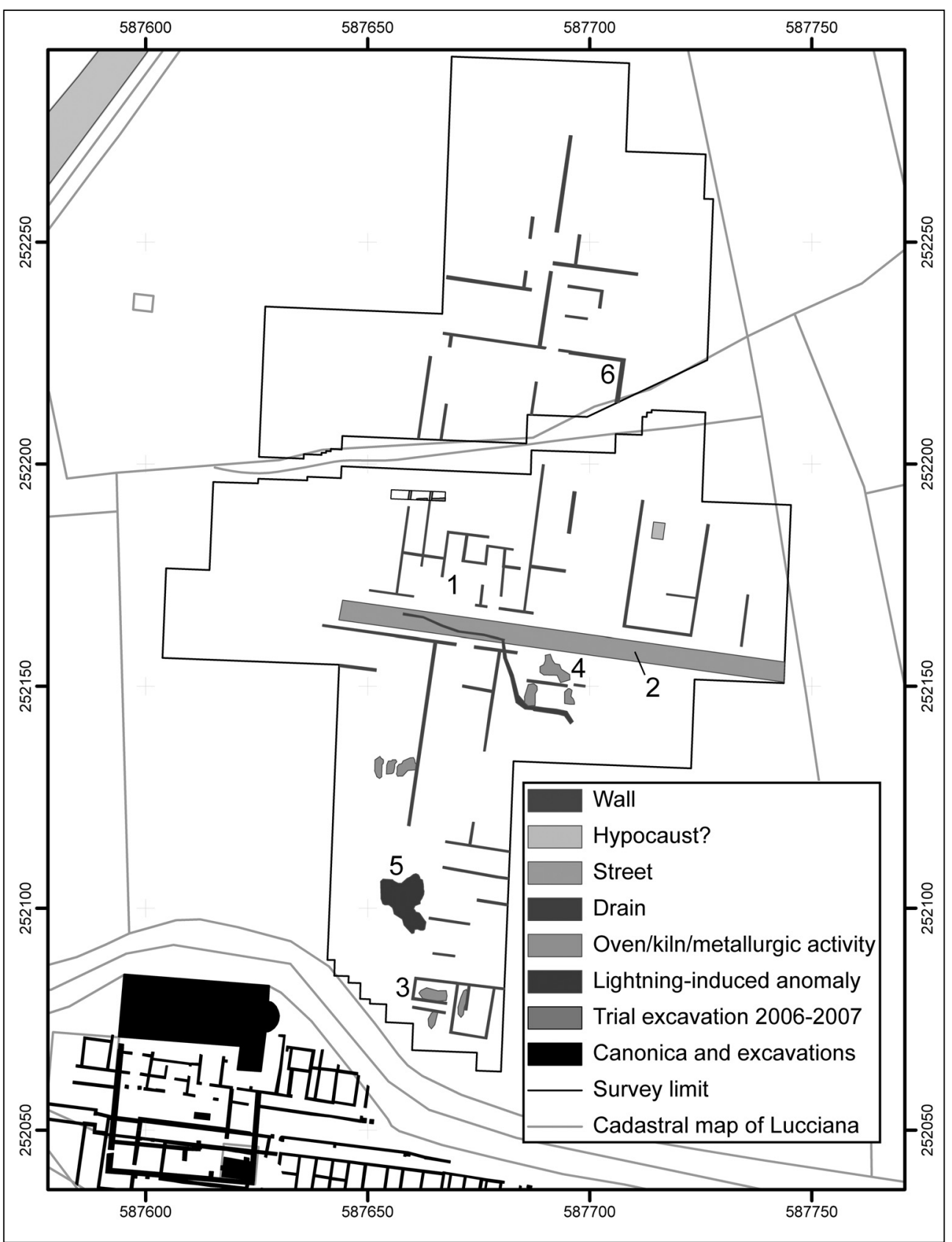

Figure 11.3: Interpretation of the fluxgate gradiometer results. For the numbers refer to text. 
part of parcel 81 (Fig. 11.3, no. 1). Given the dimensions of the survey area (c. $1.3 \mathrm{ha}$ in total), streets dividing the area were to be expected. However, only one relatively clear east-west axis (Fig. 11.3, no. 2), largely devoid of anomalies and not crossed by any wall features, was detected.

Some of the stronger, positive anomalies also seem related to archaeological remains. In area no. 3 (Fig. 11.3), a number of rectangular features $(-50 \mathrm{nT})$ suggest industrial activity (kilns?). Likewise, feature no. 4 (Fig. 11.3), exceeding $100 \mathrm{nT}$, may be caused by thermoremanent magnetisation, through the heating of building structures, better visible in the GPR data (Fig. 11.7), and perhaps suggesting an oven or a burning event (Gaffney et al. 2000). By contrast, anomaly no. $5(> \pm 50$ $\mathrm{nT}$; Fig. 11.3) can be interpreted as originating from a lightning strike. Lightning strikes can cause remanent magnetisation of soils and rocks in an area up to tens of square metres. They are recognisable by their intensity compared to other structures, but especially by their typical star-shaped, alternating positive and negative magnetic anomalies, pointing in all directions. Lightning strikes were magnetically detected in high density on the plateaus of Nasca and Palpa, Peru (Gorka et al. 2007; Fassbinder and Gorka 2009).

Also in parcel 76, the magnetic contrast between the archaeological features and the soil was weak, but there too, the orientation corresponds with the excavated remains around 'La Canonica'. A rectangular structure consists of walls, buried shallowly and with parts still visible above the surface (Fig. 11.3, no. 6). Possible structures inside the rectangle are hidden by a very strong anomaly originating from pieces of agricultural machinery that could not be moved during the survey. As will be described below, this is the location of one of the excavation trenches from the 1930s (Fig. 11.1, E; Corsi, this volume).

\section{GPR data acquisition and processing}

Initial GPR tests in September 2007 over building J (Fig. 11.5; Fig. 11.1, G) were promising. Subsequently, three different areas of the town were prospected. The northeastern part of parcel $81\left(c .5000 \mathrm{~m}^{2}\right)$ was surveyed in September 2008 (Fig. 11.1, H; Verdonck and Vermeulen 2009). The November 2009 survey comprised three smaller areas in fields 2 and 76 (c. $2700 \mathrm{~m}^{2}$ in total) where the construction of the site museum is scheduled (Fig. 11.1, I). During the same campaign, the prospection of two rectangular grids south of the excavated part of the site (Fig. 11.1, J) intended to explore the area where a new section of the D107 road is planned (Fig. 11.1, K).

The surveys were carried out using a pulseEKKO PRO GPR system with a $500 \mathrm{MHz}$ antenna. The data were recorded in 'zigzag' mode (east-west orientation, except for area $\mathrm{J}$, where the orientation was north-south), with a sampling interval along the lines of $0.05 \mathrm{~m}$ and a transect spacing of $0.25 \mathrm{~m}$. The time window was $60 \mathrm{~ns}$, the stack was 8 . 
The transects were marked on the ground by guide ropes. A digital elevation model of the relatively flat survey areas was created with a total station, with a distance between the measurement points of maximum $2 \mathrm{~m}$ in the in-line and cross-line directions, depending on the topography.

A standard processing sequence was applied. After dewow and the alignment of the zero crossings following the onset of the air-wave, a uniform gain function, based on the inverse average amplitude envelope, was applied in order to enhance later arrivals. Further steps involved the application of a band-pass filter $(100 \mathrm{MHz}-1 \mathrm{GHz})$ and background removal. The many small metal objects in the topsoil, which hampered the interpretation of the magnetometer results, were also visible in the GPR dataset, in the form of strong ringing. Since this creates large artefacts when migrated, it had to be removed. Fortunately, the amplitude spectrum of the affected traces is often characterised by a peak with a narrow bandwidth, which can be suppressed by a bandreject filter. However, since the removed frequency also contains useful information, only the affected traces are replaced with filtered ones (Verdonck et al. 2012). Subsurface velocities were estimated using constant velocity migration tests. In September 2008 these yielded a high velocity (up to $0.115 \mathrm{~m} / \mathrm{ns}$ ) for the very dry topsoil, decreasing to approximately $0.08 \mathrm{~m} / \mathrm{ns}$ at a depth of $1.2 \mathrm{~m}$. Only minor variations around the average velocity of $0.08 \mathrm{~m} / \mathrm{ns}$ were detected in the data from November 2009, collected in slightly wetter soil conditions. After the application of a two-dimensional migration algorithm, these velocity profiles were used for the time-to-depth conversion. Horizontal slices were created from the square root of the average energy in a $0.05 \mathrm{~m}$ depth range (Fig. 11.4).

Since the complex results cannot easily be interpreted on the basis of profiles or horizontal slices alone, a three-dimensional interpretation was made (Fig. 11.6) on the basis of the horizontal slices. As this process is time-consuming, for each feature one slice was selected for defining the horizontal extent: the slice where the feature had the largest extent and where the contrast with the surrounding soil was the sharpest. Furthermore, two slices were selected, representing the top and bottom of the feature. Using the depth of these slices, the feature was given its vertical extent. As most features in the dataset were walls, this simple box model with six faces can be assumed to represent the real situation relatively adequately, even if it is a simplification. Particular attention was given to possible discontinuities, such as a doorway in a wall or depth variations within a single feature.

\section{GPR results from the 2007-2008 surveys}

Figure 11.4 shows horizontal slices at different depths from parcel 81, in Figure 11.5 the archaeological interpretation is displayed. The shallowest structures appear at a depth of approximately $0.35 \mathrm{~m}$. On the shallow horizontal slices, down to an 

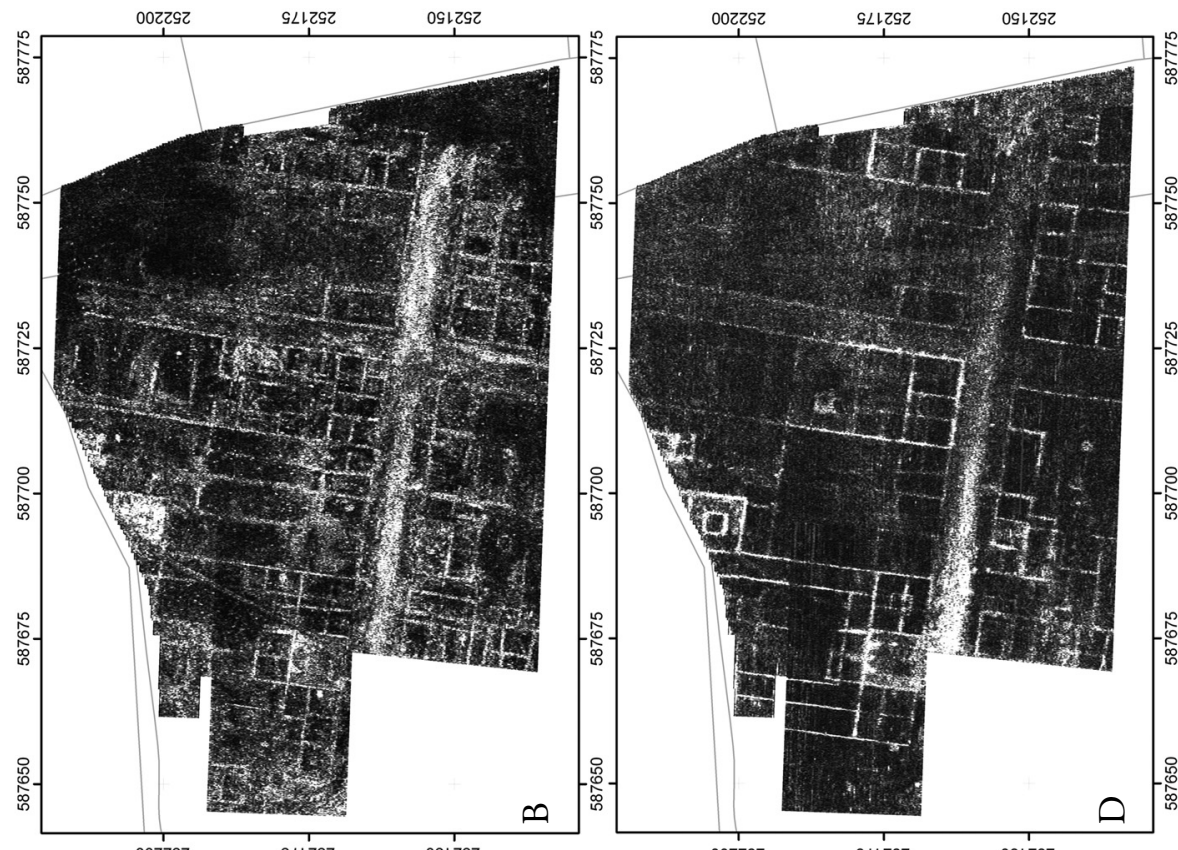

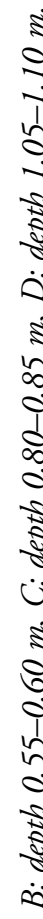
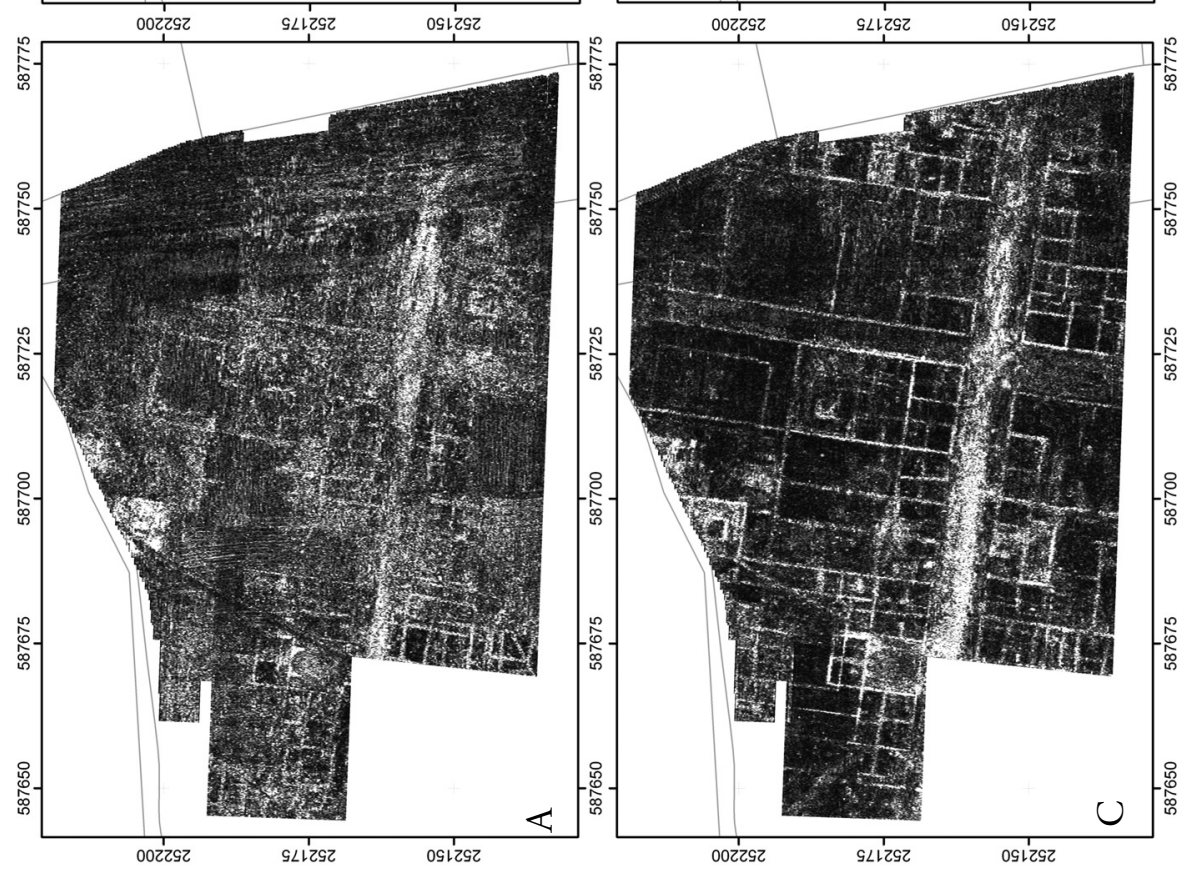

ई

nิ

in

$\stackrel{2}{1}$

ह

$\frac{2}{8}$

$\dot{+}$

के

๙ิ

¿ั.

$\frac{\pi}{6}$

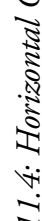

密 


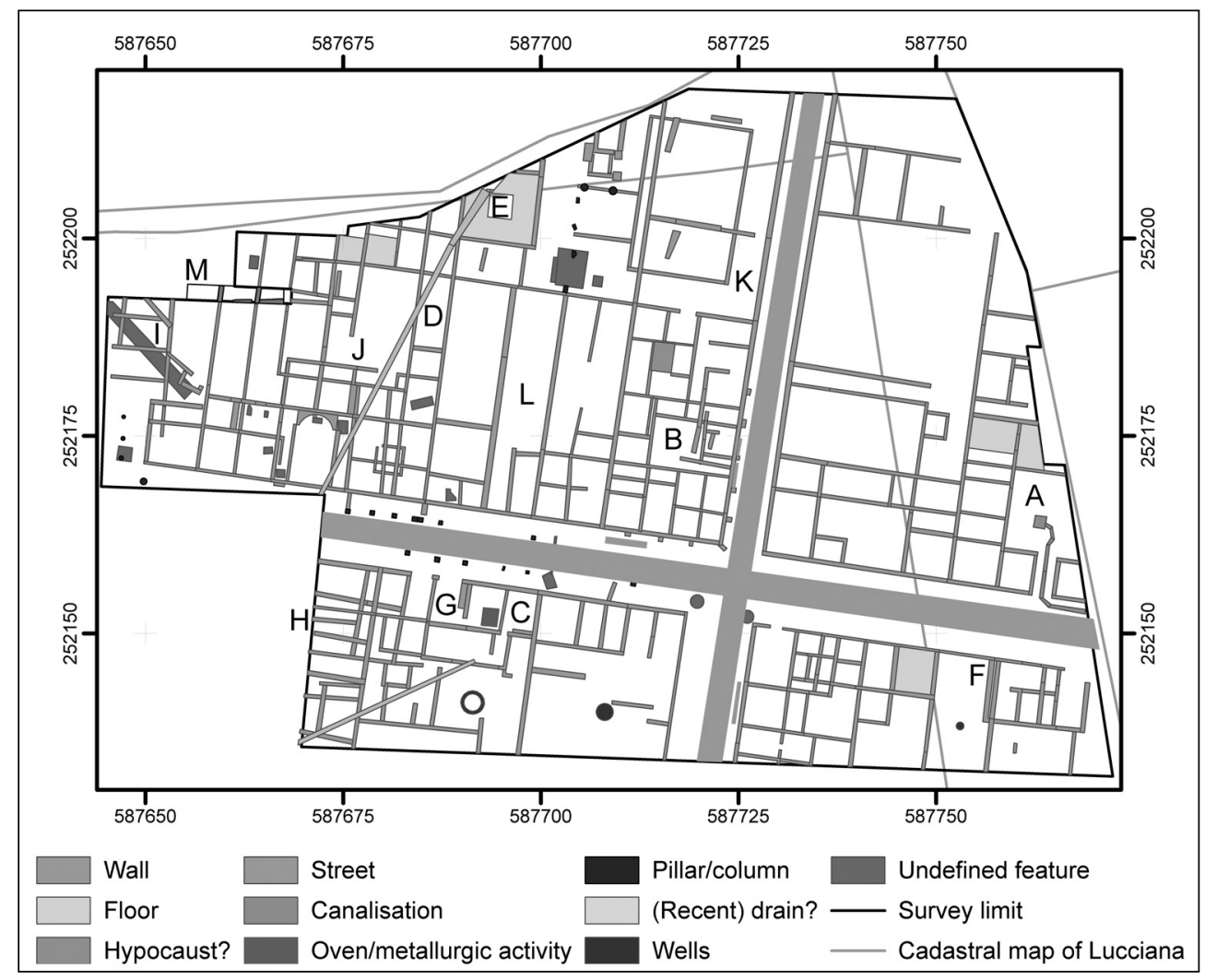

Figure 11.5: Interpretation of the 2007-2008 GPR data. A-B: houses, C: oven/metalworking workshop, $D$ : recent drain (?), E: structure cut by feature $D, F-H$ : walls suggesting structural alterations or different phases, I: shallow constructions with slightly deviating orientation, J: building with courtyard and portico (later built up), K: portico, L: building with public function (?), M: trial excavation 2006-2007.

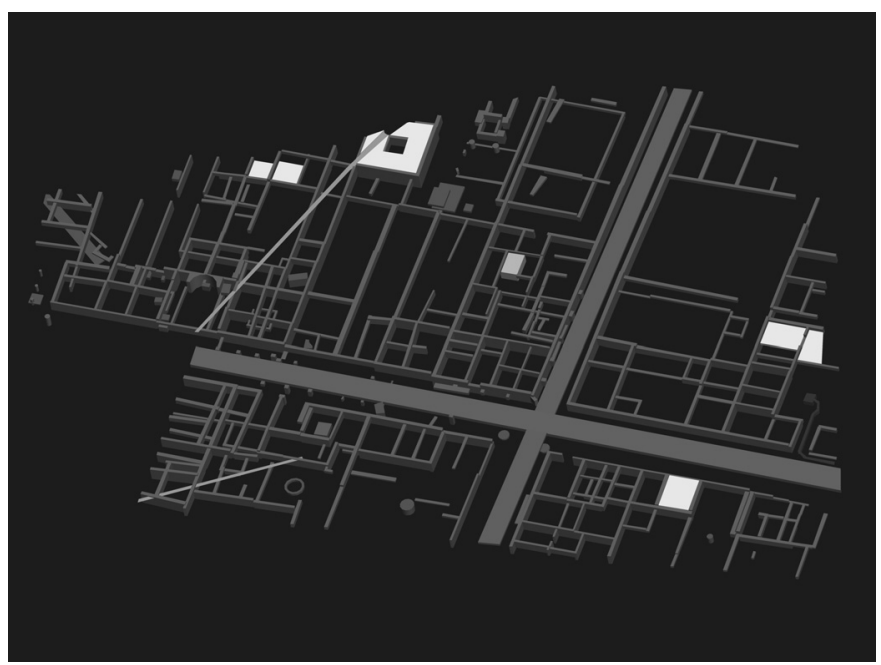

Figure 11.6: Three-dimensional interpretation of the 2007-2008 GPR data. For the colour-code, see the legend in Figure 11.5. The vertical dimensions are exaggerated with a factor two. 
approximate depth of $0.40-0.45 \mathrm{~m}$, a large amount of loose debris is visible compared to the deeper slices. This seems to indicate that there is considerable plough damage (Linford et al. 2007). The field was ploughed until c. 2000, before it was purchased by the municipality of Lucciana and converted into grasslands. The deepest foundations reach a depth of $1.4 \mathrm{~m}$.

The orthogonal street system is immediately noticeable, with two streets dividing the prospected area in four insulae and with the same orientation as the excavated colonnaded street (Fig. 11.1, B). The assumption that this excavated street corresponds to a right-angled street system can now be confirmed. The street running east-west shows a strong reflection (Fig. 11.4). Presumably it was metalled, as opposed to the north-south street. In its westernmost part, on both sides of the street a series of small reflections with a distance of $c .3 \mathrm{~m}$ can be identified as the remains of pillars or columns supporting porticoes. The northern part of the north-south street is much narrower $(c .5 \mathrm{~m})$ than the other streets $(c .8 .5 \mathrm{~m})$.

Some of the structures within the insulae can clearly be interpreted as houses. In house A (Fig. 11.5), the atrium (central hall) is clearly visible, with the impluvium (a basin where the rain water was collected under an opening in the roof) and a channel running underneath the fauces (entrance) towards the street. A reflection in two rooms at a depth of $c .0 .70-0.80 \mathrm{~m}$ can be interpreted as a floor. In the rest of the data-set few floors can be distinguished. House B (Fig. 11.5) probably also had its entrance at the east-west street. Here too, an inner courtyard can be recognised, and the walls adjacent to both streets show small buttresses. A high positive magnetic anomaly in one of the rooms, combined with a deep reflection in the GPR data $(0.75-1.45 \mathrm{~m})$ might represent a hypocaustum (underground heating system). Although their layout is less clear, most other buildings also seem private dwellings rather than monumental public buildings.

\section{Combined interpretation of GPR and fluxgate gradiometer results}

The GPR results in general allowed an easier interpretation than the gradiometer data, but the latter proved a source of complementary information in several cases. The strong positive magnetic anomalies in a building of the south-western insula (Fig. 11.5, C; Fig. 11.7A, no. 1), indicating an oven, a fire or perhaps a metal workshop, were mentioned above. The magnetic data were also useful for the reconstruction of a drain running under the east-west street, beyond the GPR survey area: a series of small positive magnetic anomalies indicates ceramic pipes or bricks. It seems to continue towards building $\mathrm{C}$ but is invisible on the GPR slices (Fig. 11.7). A long and straight reflection in the GPR data may represent another drain (Fig. 11.4 and Fig. 11.5, D), although this might also be a recent disturbance as it is relatively shallow and cuts structure E (Fig. 11.5; see also Fig. 11.8C, 8).

In several buildings, structural alterations are visible. Often, the distance between the walls is very small so that they cannot be contemporary (see e.g. Fig. 11.5, F, G, 


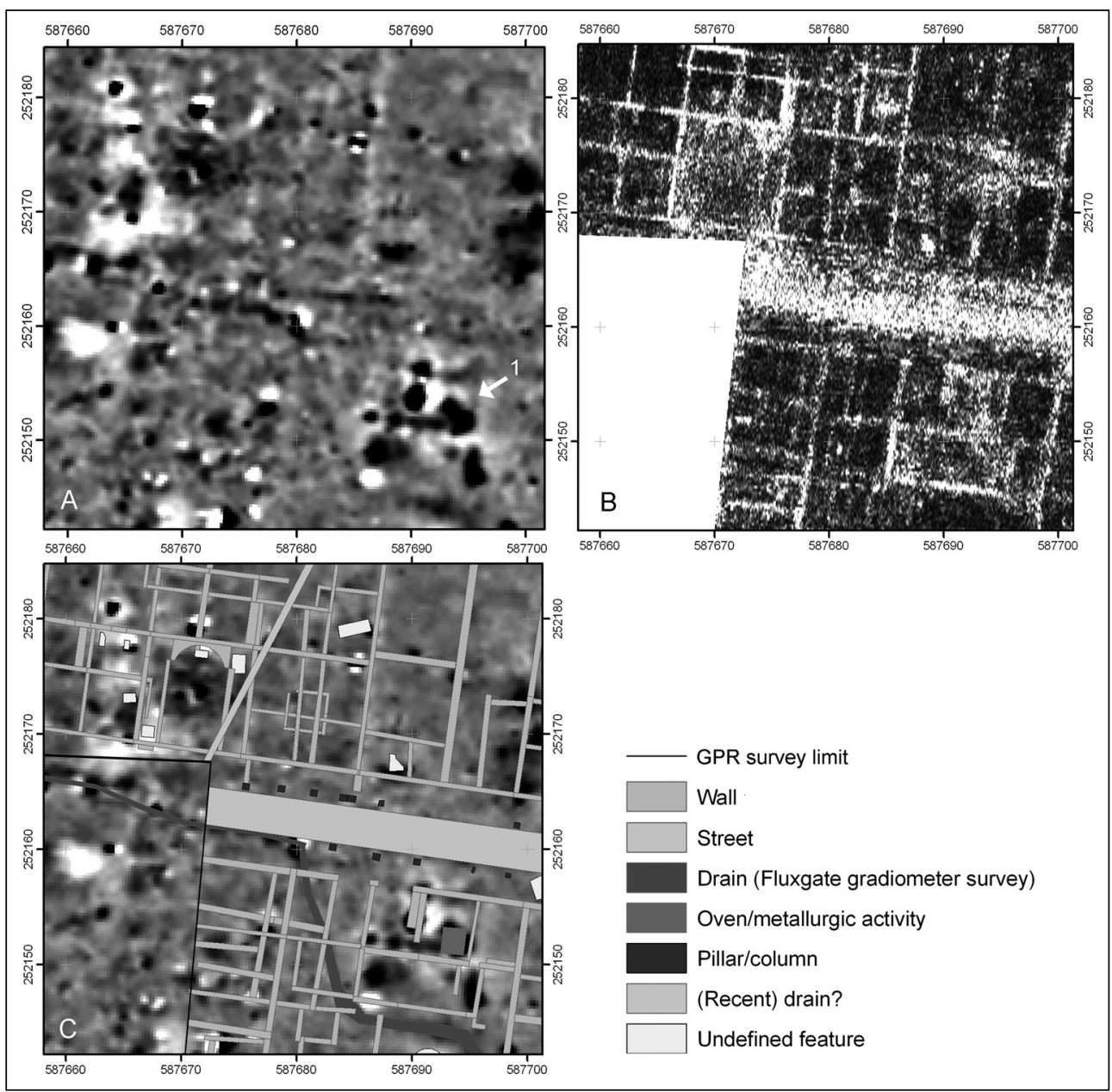

Figure 11.7: Combined fluxgate gradiometer and GPR data near a possible oven structure/metalworking workshop (no. 1). A: gradiometer data, from $-30 \mathrm{nT}$ (white) to $+30 \mathrm{nT}$ (black), B: horizontal GPR slice at 0.80-0.85 $\mathrm{m}$ depth, C: interpretation of the GPR data overlying the gradiometer data.

H; Fig. 11.6). Moreover, deep foundations, built exactly according to the orientation of the town layout and causing strong GPR-reflections, contrast with the shallower, less sturdy walls, often slightly deviating from the main orientation. An example is building I in the northwestern insula (Fig. 11.5). In building J, the deepest reflections belong to a $29 \mathrm{~m}$ wide building with a courtyard surrounded by a portico (Fig. 11.8C, no. 1; Fig. 11.9, no. 1). On the western side of the building, a wall runs parallel to the exterior portico wall, forming a $5 \mathrm{~m}$ wide corridor (Fig. 11.8C, no. 2; Fig. 11.9, no. 2). South of the courtyard are three rooms of approximately $10 \mathrm{~m}$ by $9 \mathrm{~m}$. The 


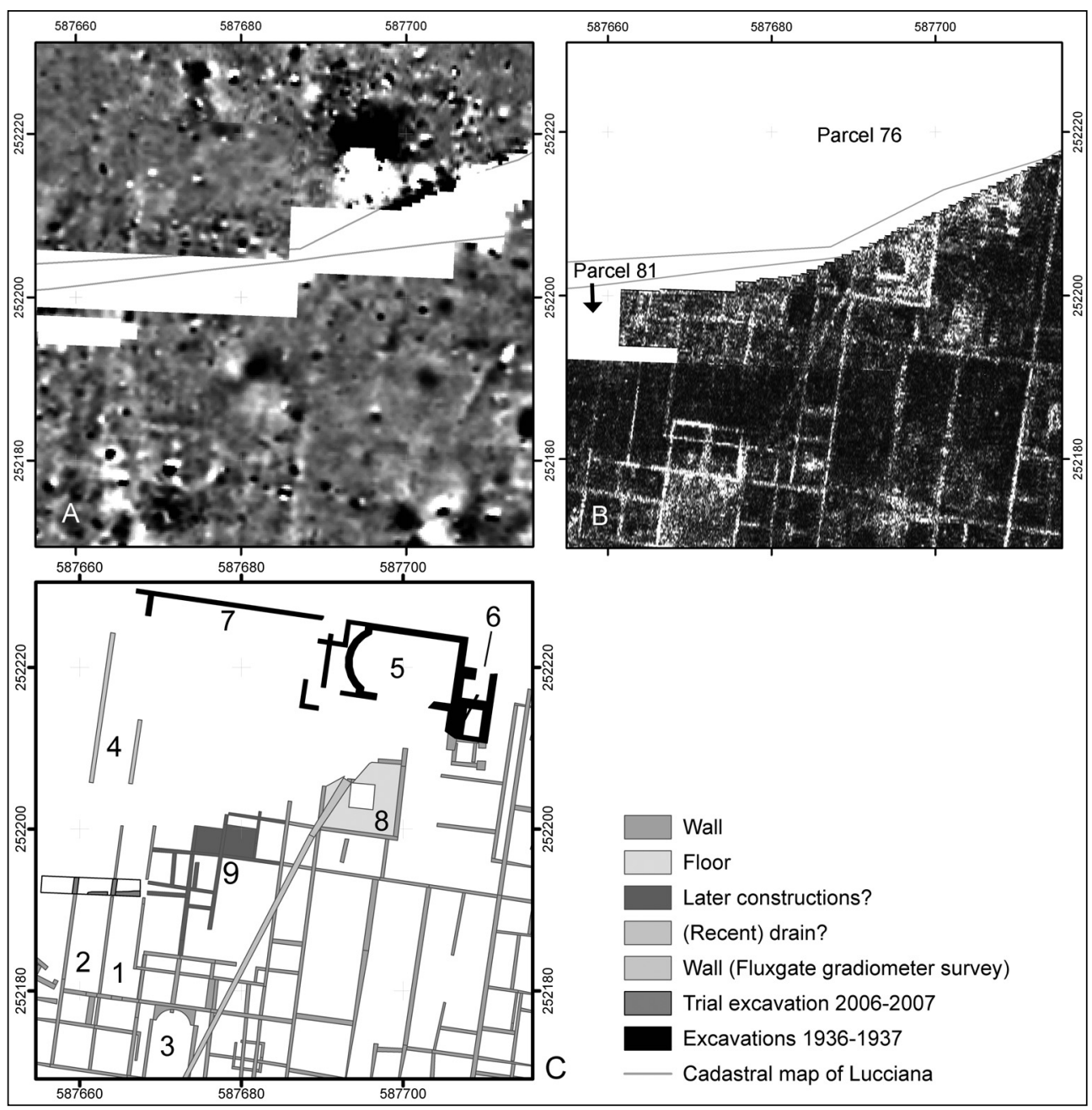

Figure 11.8: Fluxgate gradiometer and GPR data gathered over a large (public?) building complex with courtyard and possible later Roman constructions (see text). A: gradiometer data, from $-25 n T$ (white) to $+25 n T$ (black), B: horizontal GPR slice at 80-0.85 m depth, C: interpretation. 1: portico, 2 and 4: corridor, 3: apsidal room, 5-7: structures uncovered during the 1936-1937 excavations; 8: structure probably belonging to the building complex, 9: internal divisions within courtyard.

middle one appears to have a semicircular apse at its northern end (Fig. 11.8C, no. 3; Fig. 11.9, no. 3). The building might be interpreted as a public building, perhaps as a gymnasium (sports complex) or baths.

On the adjacent parcel 76 , the very uneven surface with abundant boulders precluded a good ground coupling of the GPR antenna, but the continuation of the exterior portico wall and the wall parallel to it are identifiable in the gradiometer data, although not very 


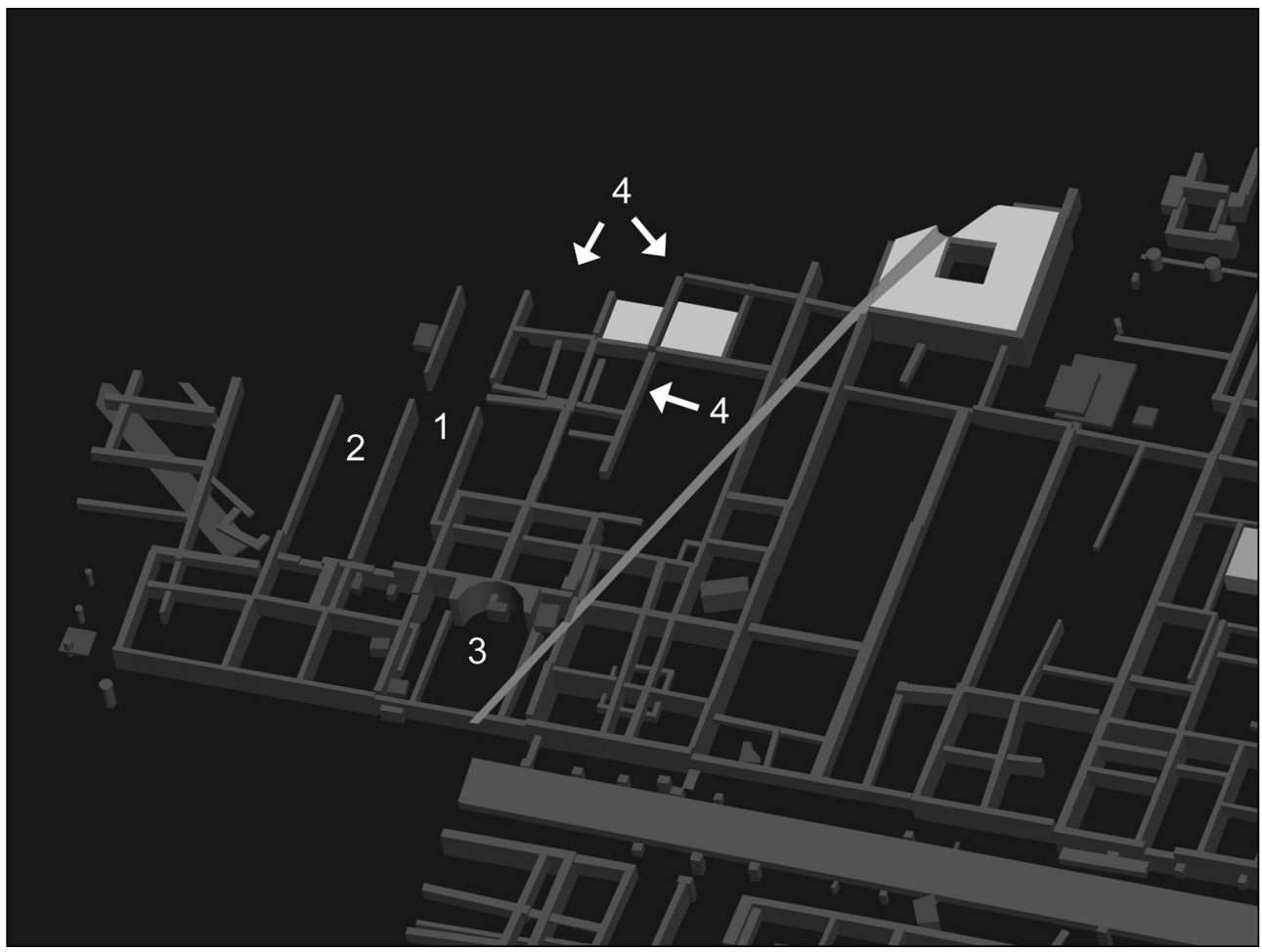

Figure 11.9: Three-dimensional interpretation of the GPR data gathered over the presumed public building in the northwestern insula. 1: portico, 2: corridor, 3: apsidal room, 4: structures inside courtyard. The vertical dimensions are exaggerated with a factor two.

clearly (Fig. 11.8C, no. 4). The combination of the GPR data on parcel 81, the fluxgate gradiometer results on parcel 76 and the mapping of a few wall foundations still visible aboveground near no. 6 (Fig. 11.8C) allowed one of the trenches, 'chantier C', from the poorly recorded 1936-1937 excavations to be located (Fig. 11.8C, nos 5-7; Corsi, this volume). In their report, the excavators describe a room of approximately $8 \mathrm{~m}$ by 11 $\mathrm{m}$ with an apse at its western side and with fragments of marble wall covering, a series of smaller rooms (no. 6) and a 26 m long east-west running wall (no. 7), all visible in the gradiometer data (Figs 11.2 and 11.8A). They assume that the remains are part of a larger building complex with a public character (Leschi and Chauvel 1937; Nucci 2001). Several other structures may have belonged to this complex, like building no. 8 (Fig. 11.8C), a double square with deep foundations, provoking a strong, shallow reflection suggesting a floor, or portico $\mathrm{K}$, which may also be the peristylium of house B (Figs 11.5 and 11.6). The function of three-aisled building L (Fig. 11.5) is more difficult to discover, but probably it also had a public function. 
In the horizontal GPR slices from a depth of $c .0 .35 \mathrm{~m}$, internal divisions are present within the courtyard of building J (Fig. 11.8C, no. 9; Fig. 11.9, no. 4). At least some indicate a different occupation phase because of the manifest differences in the construction. Some of the less robust structures can hardly be distinguished from the background noise, especially in the shallower slices (Fig. 11.4B). In the future, surveys with a closer line spacing may image them in more detail. Theoretical considerations show that a line spacing coarser than quarter wavelength leads to degraded data quality in the form of aliasing (Grasmueck et al. 2005; Booth et al. 2008; Marchesini and Grasmueck 2010): high spatial frequencies which are not properly sampled assume a lower frequency, thereby combining with lower frequency data and corrupting the latter. For an antenna with centre frequency $500 \mathrm{MHz}$ and a subsurface wave velocity of $0.08 \mathrm{~m} / \mathrm{ns}$, this criterion would amount to a line spacing of $\sim 0.04 \mathrm{~m}$. Multi-antenna GPR systems, approaching these requirements, are now available (Francese et al. 2009; Linford et al. 2010; Trinks et al. 2010). Obviously, with a single antenna, the extra data-acquisition effort is considerable. A data collection strategy in different levels can be a compromise: a coarser line spacing (up to $0.25 \mathrm{~m}$ ) for the survey of large areas, combined with targeted, full-resolution surveys over areas with a low signal-tonoise ratio or where subtle features can be expected.

In a small test excavation (Fig. 11.5, M; Fig. 11.8C and Fig. 11.10), described in more detail by C. Corsi (this volume), the walls causing strong GPR signals were found to consist of opus testaceum, with foundations of cobbles in cement. Their total depth $(c .1 .3 \mathrm{~m})$ is consistent with the GPR results. These first-second century $\mathrm{AD}$ walls were demolished down to their current depth of $0.55 \mathrm{~m}$ below walking level not later than the end of the third century $\mathrm{AD}$, and an east-west alignment of loose cobbles (Fig. 11.10), corresponding to a weaker GPR reflection, was found on top. As a consequence, it seems likely that at least some of the shallow GPR reflections inside the courtyard belong to a later phase. Further excavations are necessary to provide chronological information on similar cases elsewhere in the GPR dataset.

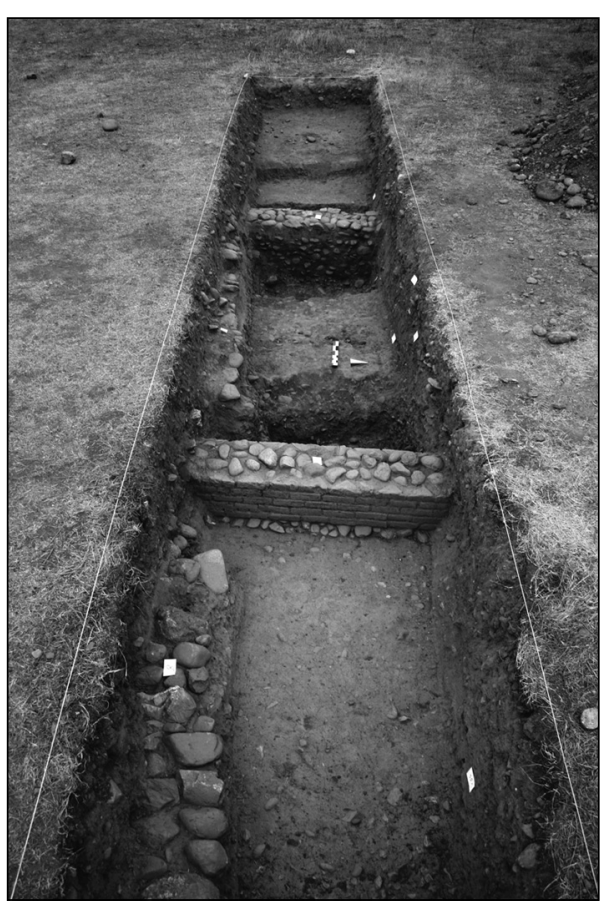

Figure 11.10: Trial excavation ( $12 \mathrm{~m}$ by $2 \mathrm{~m}$ ) showing walls in opus testaceum and cobble alignments. For its position, see Figure 11.5, M (photo: F. Vermeulen). 


\section{The 2009 GPR surveys}

Whereas the GPR and gradiometer survey on parcel 81 and the southern part of parcel 76 aimed at providing information on the Imperial town centre and the intra mural street network, the GPR prospection south of the 'La Canonica' excavation zone (Fig. $11.1, \mathrm{~J}$ ) addressed the question whether the southernmost excavated remains (Early Christian cathedral with baptistery and Roman market; see Corsi, this volume) were built at the border of the ancient town or, alternatively that the city continued to the south.

On the horizontal slices from the two grids, only a few anomalies belong to the ancient town, and all are close to the fence surrounding the excavations (Fig. 11.11). The most important ones are located in the eastern grid, and can be interpreted as the outer walls of a small rectangular building, visible at a depth of approximately $0.20-1.65$ $\mathrm{m}$. The resemblance with the plan and description of 1936 'chantier A' (Corsi, this volume) is obvious. The excavators describe a building, $c .8 .5 \mathrm{~m}$ long and $7.5 \mathrm{~m}$ wide, as the caldarium (hot room) of a bath complex with a hypocaustum and foundations reaching a depth of almost $3 \mathrm{~m}$ below walking level. At the time of the excavation, a number of pilae (small pillars which allowed the hot air to circulate underneath the floor) were still intact, others had been replaced by brick walls (Leschi and Chauvel 1936). These pilae were removed by the excavators.

Apart from a small structure to the west of the caldarium, nothing was revealed in the surroundings by the GPR. As the excavation was limited to the interior, no comparative excavation data are available for the area outside the caldarium. In the western grid, no archaeological features were detected except a few small structures, close to the fence.

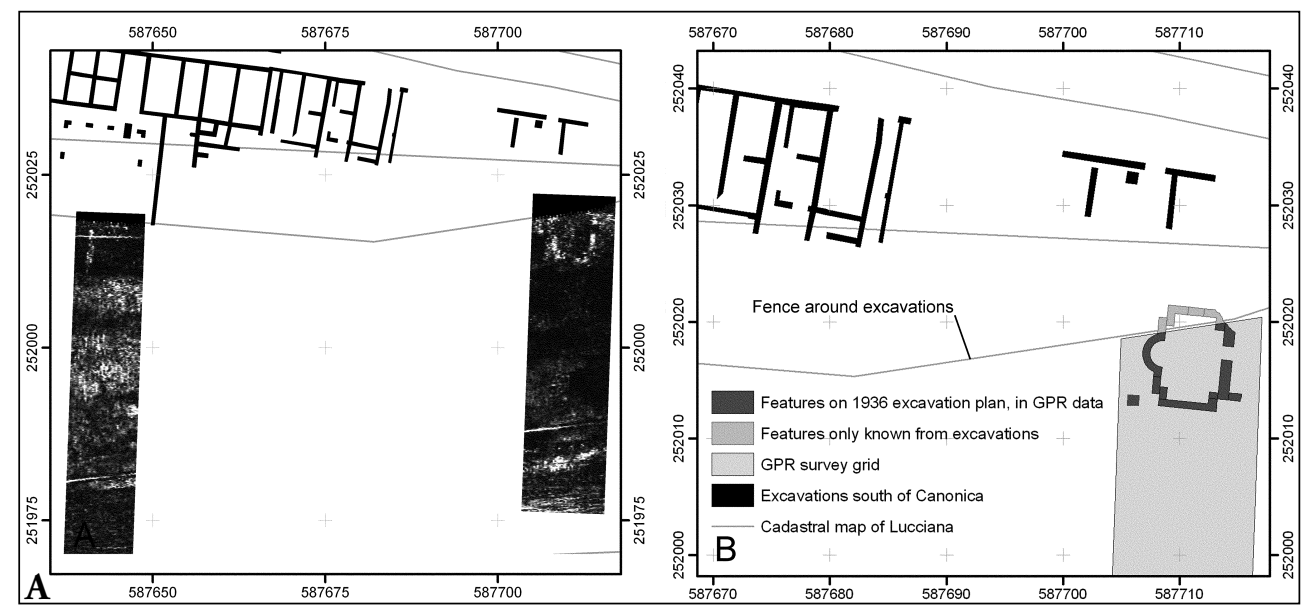

Figure 11.11: GPR survey south of the 'La Canonica' excavation area. A: horizontal GPR slice at 0.45-0.50m depth, B: interpretation of the archaeological structures, which were the object of one of the 1936-1937 excavations ('chantier A', bathhouse). 
This scarcity of archaeological features corresponds with the results of the geomorphological soundings carried out since 2000 by A. Roblin-Jouve (University of Paris X Nanterre; Corsi et al. 2009). These have clarified the relationship between the town and the river Golo, which today flows a few tens of meters south of the excavation area near 'La Canonica' (Fig. 11.1, L). Part of the town was built in a river bed older than the first century $\mathrm{AD}$. The water level remained low until the sixth century,

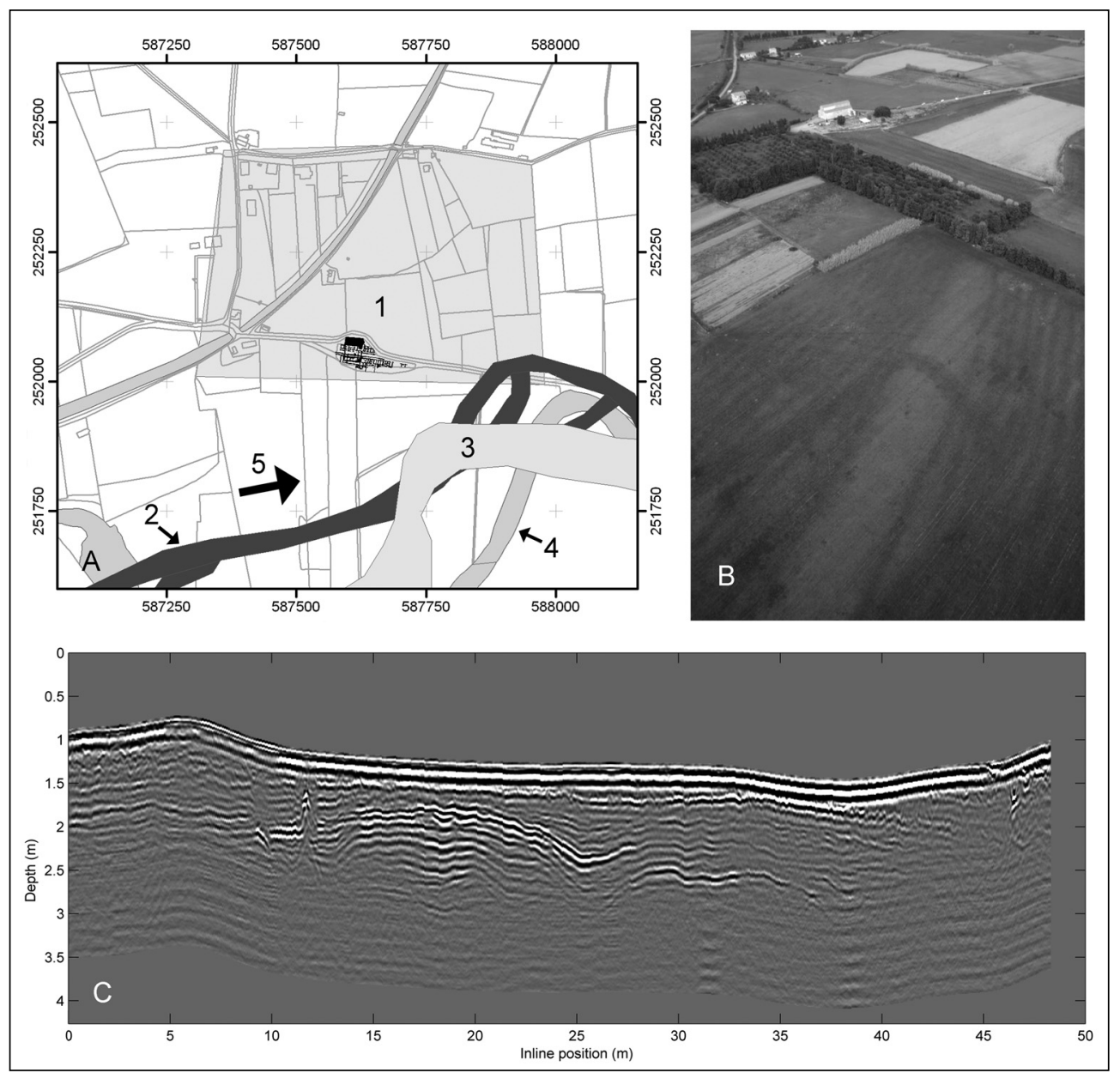

Figure 11.12: Traces of old beds of the river Golo. A: From historical maps, a southeastward shift of the Golo can be reconstructed (adapted from Corsi et al. 2009), 1: hypothetical extent of Mariana, 2: course of the Golo in 1785, 3: situation in 1900, 4: present situation, 5: position of the river bed on the aerial photograph in B (photo: F. Vermeulen); C. GPR profile (from south to north) from the western survey grid south of 'La Canonica' (see Fig. 11.11), showing ancient beds of the Golo between $25 \mathrm{~m}$ and $40 \mathrm{~m}$. 
although flooding occurred sporadically. However, in the medieval period (probably between the tenth and twelfth century), the Golo destroyed parts of the town, which originally extended further to the south. The river deposited an enormous volume of loamy sediments, under which some of the remains may have been preserved, and completely filled up the bed existing in the Roman period. Subsequently, it gradually moved southeastwards, towards its current position (Fig. 11.1, L; Fig. 11.12A). The GPR data collected in 2009 in both grids J (Fig. 11.1) illustrate this evolution: in a profile from the western grid, different superimposed layers slope down towards a point at approximately $25 \mathrm{~m}$, and the area between $25 \mathrm{~m}$ and $40 \mathrm{~m}$ probably represents one or more stages in the shift of the river bed (Fig. 11.12C), which has also been recorded on aerial photographs (Fig. 11.12B).

The prospection in area I (Fig. 11.1), close to the presumed northern limit of the town, has revealed few traces attributable to ancient Mariana. Probably the foundations in this area are in a poor state of preservation, and ploughing damage is more severe. Parcel 76 was used as an arable field until 2008 and its surface is littered with cobbles and fragments of tegulae and pottery, so that only the northern part was available for GPR survey. It is possible that a large amount of debris in the topsoil has masked the deeper buried archaeology. The clearest element is a wall, approximately $0.50 \mathrm{~m}$ wide, visible over nearly $7.5 \mathrm{~m}$, with the same orientation as the structures in parcel 81 and in the 'La Canonica' excavations (Fig. 11.13B, no.1). This is in contrast with the fluxgate gradiometer results from the southern part of parcel 76 , where several structures are visible (Figs 11.2 and 11.3). This northward decrease in visibility will be the object of further investigations.

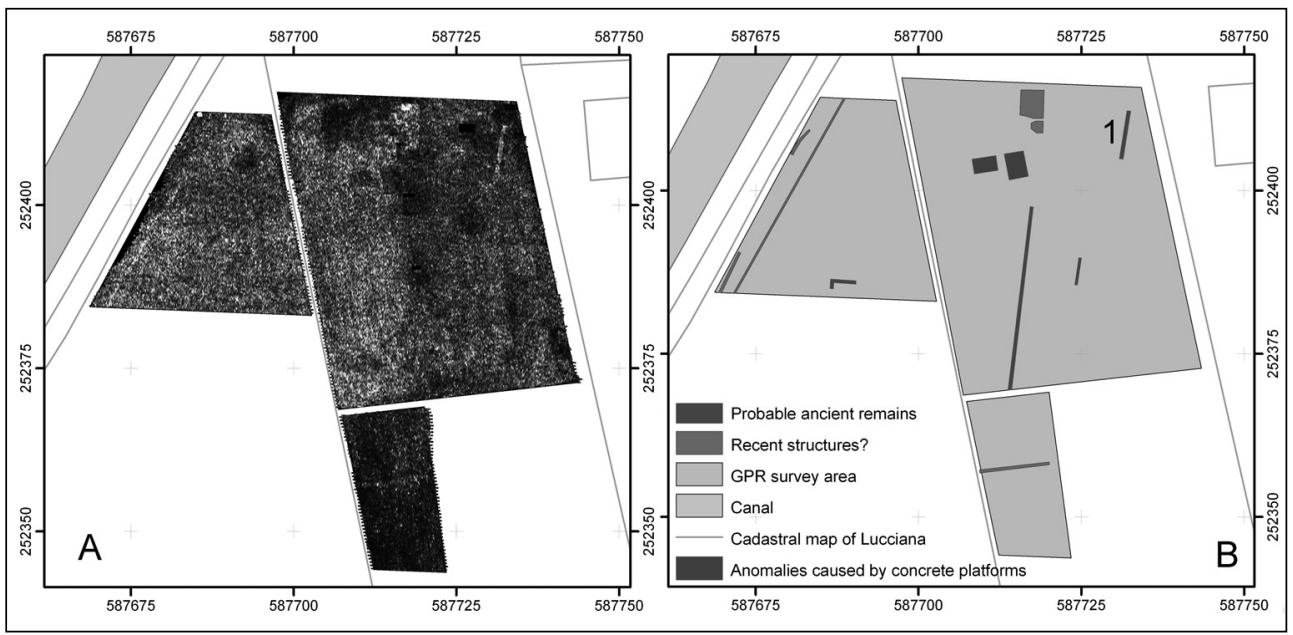

Figure 11.13: A: Horizontal GPR slice (0.35-0.40 m) from the northern survey area, B: interpretation of the results. 1: clearest wall feature, respecting the dominant orientation of the ancient town. 


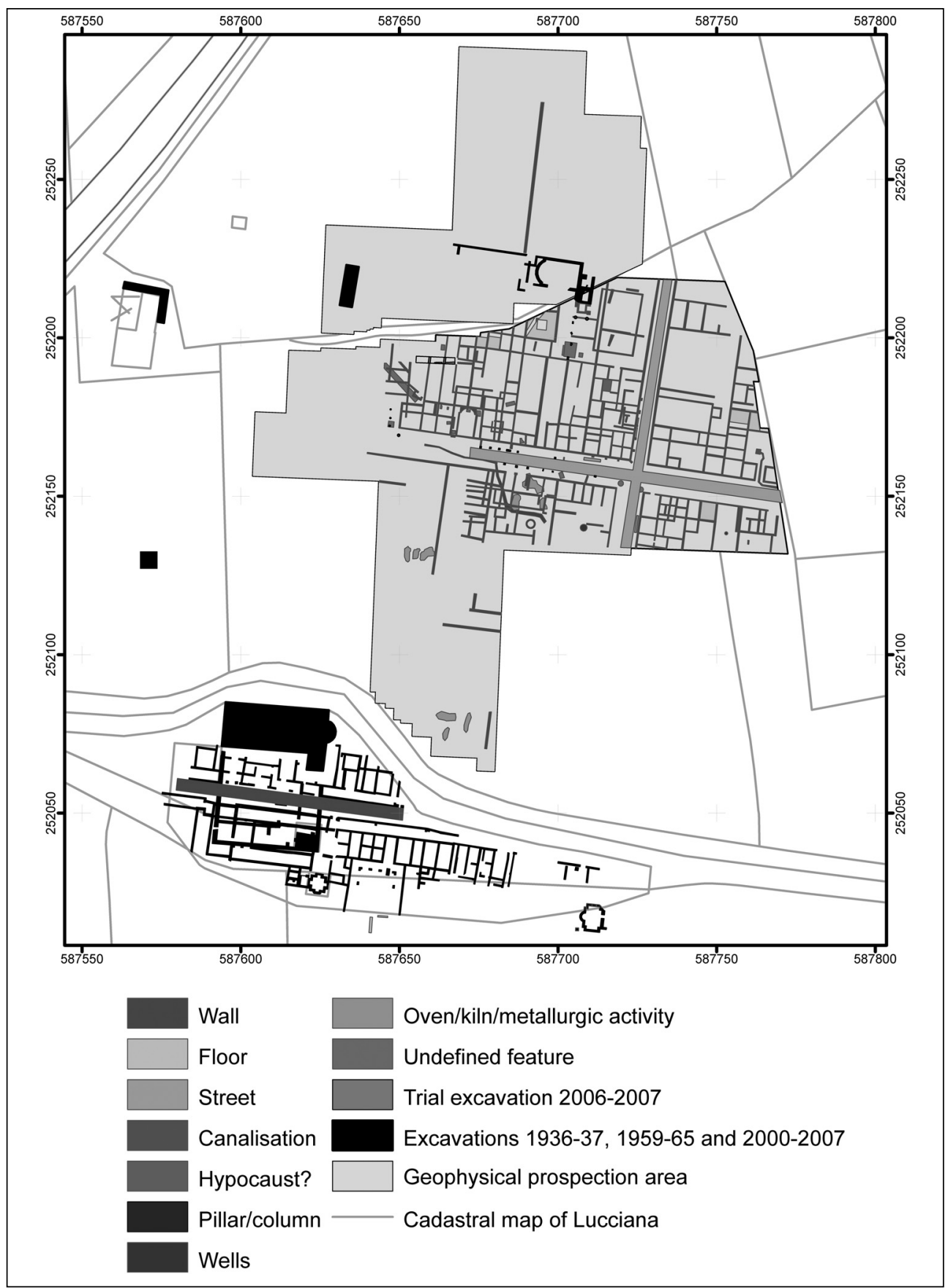

Figure 11.14: Overview of all traces detected by fluxgate gradiometer and GPR survey at Mariana (except for the northern GPR survey area, see Fig. 11.1, I and Fig. 11.13), and all intra muros excavation results. 


\section{Conclusion}

This paper has stressed the role of geophysical prospection in reconstructing the layout of the Roman town of Mariana, and the integration of geophysical data with other available information, especially from excavations (Fig. 11.14). At present, the main questions (location of the Imperial town centre as well as the town perimeter, characterisation of the street network) can be answered as follows. The presence of two orthogonal streets in the GPR data now confirms the hypothesis that an excavated east-west axis belongs to a right-angled street system, as it is known in many Roman cities. Most buildings can be interpreted as private houses, except for some possible kiln structures in the southern part of the survey area, and a presumed public building complex in the western part. Old excavation reports describe part of this complex in detail, and in the fluxgate gradiometer and GPR data a courtyard surrounded by a portico can be distinguished, with shallow structures inside it. A small trial excavation has shown that these structures with different construction quality belong to different phases in the town's history, but no precise function can yet be attributed to the building. The monumental centre of Early Imperial Mariana may hence be situated more to the west or northwest, as can also be expected from the presence of a large concrete podium preserved under a modern house with the toponym 'Imperiale'.

An area close to the presumed northern limit of the town revealed few traces, although some elements confirm that the town extended this far north. In the zone south of the main excavation area near the 'La Canonica' church, which was the scene of the complex interaction between the river Golo and the town, no archaeological features could be detected, but an old river bed was identified.

\section{Acknowledgements}

The author would like to thank Frank Vermeulen and Cristina Corsi, who directed the prospections and excavations by Ghent University and University of Cassino, and Philippe Pergola (Maison Méditerranéenne des Sciences de l'homme, Aix-en-Provence), who directed the 2000-2007 excavations around 'La Canonica'. This study took place within the Groupement de Recherche Européen 'Le monde insulaire en Méditerranée - approche archéologique diachronique des espaces et des sociétés', supported by the C.N.R.S. Many thanks also to Francesca Carboni and Caterina Venditti for the valuable information from the 2006-2007 excavations on parcel 81, to Annie Roblin-Jouve (Maison Ginouvès, Paris) for the joint geoarchaeological fieldwork and the exchange of data, to Daniel Istria, director of the Mariana project, to Joseph Cesari, Conservateur régional de l'archéologie, to Isabelle Dahy (municipality of Lucciana) and to the Association culturelle de Mariana et de la Basse Vallée du Golo. This study would not have been possible without the financial support of the Fund for Scientific Research - Flanders and the Special Research Fund of Ghent University. 


\section{Bibliography}

Aspinall, A., Gaffney, C. And Schmidt, A. 2008. Magnetometry for Archaeologists. Geophysical Methods for Archaeology 2. Lanham: AltaMira Press.

Benech, C. 2007. New approach to the study of city planning and domestic dwellings in the Ancient Near East. Archaeological Prospection 14. 87-103.

Booth, A. D., Linford, N. T., Clark, R. A. and Murray, T. 2008. Three-dimensional, multi-offset ground-penetrating radar imaging of archaeological targets. Archaeological Prospection 15. 93-112.

Corsi, C., Roblin-Jouve, A. and Vermeulen, F. 2009. Géoarchéologie autour de la ville romaine de Mariana et de la basse vallée du Golo. In De Dapper, M., Vermeulen, F., Deprez, S. and Taelman, D. (eds) Ol'Man River. Geo-archaeological Aspects of Rivers and River Plains. 257-272. Ghent: Academia Press.

Fassbinder, J. W. E. and Gorka, T. H. 2009. Beneath the desert soil. Archaeological prospecting with a Caesium Magnetometer. In Reindel, M. and Wagner, G. A. (eds) New Technologies for Archaeology. Multidisciplinary Investigations in Palpa and Nasca, Peru. 49-69. Berlin-Heidelberg: Springer Verlag.

Francese, R. G., Finzi, E. and Morelli, G. 2009. 3-D high-resolution multi-channel radar investigation of a Roman village in Northern Italy. Journal of Applied Geophysics 67. 44-51.

Gaffney, C. F., Gater, J. A., Linford, P., Gaffney, V. L. and White, R. 2000. Large-scale systematic fluxgate gradiometry at the Roman city of Wroxeter. Archaeological Prospection 7. 81-99.

Gorka, T., Fassbinder, J. W. E. and Lambers, K. 2007. Magnetometry on the geoglyphs of Palpa and Nasca (Peru). Studijné Zvesti Archeologického Ústavu SAV 41. 176-178.

Grasmueck, M., Weger, R. and Horstmeyer, H. 2005. Full-resolution 3D GPR imaging. Geophysics 70. K12-K19.

Keay, S., Millett, M., Paroli, L. and Strutt, K. 2005. Portus. An Archaeological Survey of the Port of Imperial Rome. Archaeological Monographs of the British School at Rome 15. London: The British School at Rome.

Leckebusch, J. ANd Sütterlin, H. 2007. Large scale GPR surveys in Augst. Studijné Zvesti Archeologického Ústavu SAV 41. 210-212.

Leschi, L. and Chauvel, A. 1936. Rapport sur les fouilles de Mariana (Corse). Unpublished report.

Leschi, L. and Chauvel, A. 1937. Campagne de fouilles effectuées en l'année 1937 à Mariana (Corse). Unpublished report.

Linford, N., Linford, P., Martin, L. and Payne, A. 2007. Geophysical evidence for assessing plough damage. Studijné Zvesti Archeologického Ústavu SAV 41. 212-213.

Linford, N., Linford, P., Martin, L., and Payne, A. 2010. Stepped frequency ground-penetrating radar survey with a multi-element array antenna: results from field application on archaeological sites. Archaeological Prospection 17. 187-198.

Marchesini, P. ANd GrasmueCK, M. 2010. Impact of spatial sampling and antenna polarization on 3D GPR fracture detection. In Proceedings of the 13th International Conference on Ground Penetrating Radar, Lecce 21-25 June 2010. doi: 10.1109/ICGPR.2010.5550193.

Neubauer, W., Seren, S., Hinterleitner, A., Löcker, K. and Melichar, P. 2009. Archaeological interpretation of combined magnetic and GPR surveys of the Roman town Flavia Solva, Austria. In Marguerie, D. and Lanos. P. (eds) Mémoire du sol, espace des hommes. 225-228. Rennes: Presses Universitaires de Rennes.

Nucci, F. 2001. Les campagnes de fouilles à Mariana (Corse) en 1936 et 1937 par Louis Leschi et Albert Chauvel. Cahiers Corsica 195.

Trinks I., Johansson, B., Gustafsson, J., Emilsson, J., Friborg, J., Gustafsson, C., Nissen, J. and Hinterleitner, A. 2010. Efficient, large-scale archaeological prospection using a true threedimensional ground-penetrating radar array system. Archaeological Prospection 17. 175-186. 
Verdonck, L. and Vermeulen, F. 2009. GPR survey at the Roman town of Mariana (Corsica). In Marguerie, D. and Lanos, P. (eds) Mémoire du sol, espace des hommes. 241-243. Rennes: Presses Universitaires de Rennes.

Verdonck, L., Vermeulen, F., Corsi, C. and Docter, R. 2012. Ground-penetrating radar survey at the Roman town of Mariana (Corsica), complemented with fluxgate gradiometer data and old and recent excavation results. Near Surface Geophysics. 10.35-45. doi: 10.3997/1873-0604.2011034. 